\title{
The Evolution of the Western Dragon
}

\author{
By Sharon Khalifa-Gueta*
}

The figure of the dragon seems to be magnetic for human imagination and flourishes even these days. In the present article I explore the biological and psychological reasons why dragons were initially created in the human mind. Although I focus on the Mediterranean dragon figure as it evolved over time, the theories I suggest here for the reasons for the creation of dragons hold globally. I discuss the origins of the dragon figure in snakes, explain the reasons for the various kinds of imagined dragons, and categorize the different dragon prototypes that developed in the Mediterranean region. This article provides basic information that can be the foundation for further study of the subject.

Keywords: Art, Dragon, Life metaphor, Snake, Underworld

\section{Introduction}

It seems to me that choosing to explore the meaning and function of the dragon figure is to come face to face with one of mankind's most fascinating phenomenon: The dragon is one of the most intriguing products of the human imagination, and we can find images of dragons in all cultures from as early as the prehistoric era. The dragon's popularity soared in all of the major ancient cultures - Mesopotamian, Indo-European, Chinese, and Egyptian, as well as pre-Colombian cultures. In this article, I focus on dragon images in ancient and medieval Mediterranean cultures that constituted an inspiration for the figure of the dragon in Early Modern Europe. The long-term popularity of the dragon figure in Mediterranean cultures is proof that it serves a psychological need. The dragon image was modified in different ways in every period and culture, adjusting to every specific cultural need.

What is a dragon then? A dragon is a reptile whose image is based primarily on the figure and features of a snake, but other animals can also be considered as inspirations for the dragon image: a whale, a crocodile, a lizard, a basilisk, and more. In ancient cultures the difference between a snake and a dragon is very vague - in ancient times, several particular snakes were believed to be divine and were worshipped. The distinction between a snake and a dragon is a relatively modern concept (therefore, this distinction will be ignored throughout this article. Furthermore, modern culture postulates the size of dragons as humongous, in contrast to the actual, relatively small size of snakes. Yet, tiny dragons were depicted from the very beginning; therefore, this distinction is not relevant in ancient visual evidence).

Evidence of the image of the dragon in prehistoric times can be seen in the excavation site of Göbekli Tepe, where there is evidence of two dragon-snake figures (Schmidt 2010: 247, 252). In the Americas, we find pre-Colombian

${ }^{*} \mathrm{PhD}$ Candidate, Ben-Gurion University of the Negev, Israel. 
evidence for dragons in various cultures and areas (Warburg and Mainland 1939: 277-292, Klein 1988, Bonfiglioli et al. 2004: 91-57, Bonfiglioli 2008: 34-41, Taube 2010: 202-219). The Australian Aboriginal cultures also have several dragon tales, such as the famous Wawilak sister and the rainbow dragon myth (Knight 1983: 21-50).

The appearance of the dragon in so many different and separate cultures all over the world suggests many possible reasons for the appearance of this image, thoroughly summed by Robert Blust in his article 'The Origin of Dragons' (2000: 519-536). In this essay I suggest two different possible origins of the image:

1. The dragon figure is a myth that dates back to a time before the great migration periods: the migration to Australia in ca. 50,000 BCE, and the migration to the Americas in ca. 12,000 BCE (Harari 2011: 70-76 [translated from Hebrew]).

2. The dragon figure is a converging of a life metaphor based on the human physiognomy. That is, the human vertical axis led to many concepts in which high and vertical represent good and healthy. The dragon, which started as a snake, is the absolute opposite - horizontal and located in the lowest zone (Lakoff and Johnson 1980).

Whether the dragon figure arising separately but simultaneously in all these cultures with similar features suggests that it is a result of the human life metaphor or whether the myth is older than the migrations is a question that I cannot answer, but I believe that the two theories are complementary and not divorced from one another.

Nonetheless, this article aims to follow the life metaphor method when examining snakes' biological features, demonstrate a human reaction to them, and analyze the development of dragon images from snakes throughout time in human interpretation that goes far beyond. This article has two parts; it begins with an analysis of snakes' caricatures and the qualities attributed to them by humans, and continue to a basic survey of the evolution of these features in western civilization up until the early modern period.

This article answers two basic questions that lack a direct explanation in dragon studies. The first is the recurring question of whether the dragon figure originated from and is analogous to snakes. The second part, which demonstrates the dragon's figure evolution in Mediterranean cultures, follows both the basic thematic interpretation of the dragon's figure, while simultaneously challenging this perspective by presenting alternative interpretations that existed at the same time.

The sociobiological aspect of the dragon was investigated by David E. Jones (2002), who studied monkeys' distress signals and noted that monkeys exhibit three separate distress calls for three separate groups of animals: reptiles, mammals, and birds. Jones labeled the distress call owing to the presence of reptiles 'brain-dragon' and claimed them to be a result of the fear of dangerous reptiles, such as dinosaurs, which is imprinted in the mammalian brain. Lynne A. Isbell (2009) elaborated this assumption and claimed that the existence of snakes 
in the living surrounding of primates was the cause of improved sight.

The literary sources for ancient Mediterranean dragons have been discussed at length by several scholars: initial consideration of this subject should be credited to Charles Daremberg, who wrote about the Greco-Roman dragon in his Dictionnaire des Antiquitès Grecques et Romaines (1877-1904: 403-414), and portrayed the dichotomy in the approaches toward the dragon figure in connection with the issue of goodness and evil. Resorting to comparative methodology, Joseph Fontenrose's Python (1980), Bernard F. Batto's Slaying the Dragon (1992), and Calvert Watkins's How to Kill a Dragon (2001) present the pre-Greco literary evidence from Mesopotamian, Near-Eastern, and Indo-European literature from before the Greek conquest. Neil Forsyth's The Old Enemy (1987) deals with dragons and other monsters as part of the royal lexicon presenting the king as a military commander, a builder of cities, and a judge who proclaims laws and enforces them, a figure who combats chaos and rebellion in all spheres of life. Daniel Ogden's 2013 books Dragons, Serpents and Slayers in the Classical and Early Christian Worlds (2013a) and Drakōn (2013b) surveys the traditional myths together with the folkloric sources and analyzed structures of symbolism attached to the dragon sign. Ogden offers a crucial survey for understanding the dragon figure and adds visual sources to his analyses.

The present article traces the evolution of the dragon figure in antiquity from the physiognomy of the snake to the figure of the dragon and maps Mediterranean dragons in basic outlines that might provide a basic structure for future study of the dragon image.

\section{The Formation of the Dragon Figure in Mediterranian Cultures}

Before exploring basic qualities that were evident in the human-snake life metaphor, a clarification of the myriad myths concerning dragons is in order. The basic structure of the Mediterranean dragon figure portrays the dragon to be man's adversary. Nonetheless, a crucial literal and visual mass of evidence contradicts this initial assumption. In his book The Old Enemy, Forsyth (1987: 38-42) explores many myths that describe a combat scene between a god - mostly a solar or storm god - and a dragon. He emphasizes that the 'dragon-slayer' myth was born out of the concept of the king as a builder of a city and the dragon was portrayed in the royal lexicon as being in opposition to the king, who stands for order and construction versus chaos and destruction.

In classical - primarily Greco-Roman - cultures, we encounter with the word 'drakōn' as a definition for this reptilian figure in Greek ('drakaina' is the word for a female dragon and 'drakontes' is the plural), and 'draco' in Latin ('dracones' in plural) (Ogden 2013b: 2). In Here Be Dragons Ariane and Christian Delacampagne's (2003: 129) note that this word comes from the verb 'seen' or 'to see', which is related to the snake being lidless, as well as to the perception of the dragon as a being that preceded the creation of the world, and thus witnessed it. I agree with Daremberg (1877-1904: 403-414) initial suggestion that in the GrecoRoman era, 'draco' meant snakes in general and not a specific species. 
The theme of the good and the evil dragon is a by-product of JudoChristianised dichotomic concepts that should also be clarified. Several dragons are beneficiaries: Agathos Daimon was a good protective demon (Dunand 19811999: (1/1) 227-282, Sfameni-Gasparro 1997: 67-109, Hillard 2010: 160-172, Ogden 2011a: 34-39, 90-95, Ogden 2011b: 149-160, Ogden 2012: 277-294, Ogden 2013b: 286-309.). The serpents allied with Asclepius and Hygieia are associated with healing (Gočeva 1981-1999: (5.1) 554-572, Edelstein and Edelstein 1998: (2) 87-90, Krug 1993: 120-187, Stafford 2000: 147-171, Stafford 2005: 120-135, Stafford 2007: 71-85, Ogden 2013b: 310-346). Zeus Meilichois was depicted as a dragon that was connected to prosperity (Lalonde 2006, Larson 2007: 21-23, 45-47, 62-69, 103-120, Ogden 2013b: 272-283). Also, when considering dragons that heroes fought against, we note that most were posed by a god as guardians of a treasure of some sort, such as the dragon of Ares that was killed by Cadmos (Euripides 1994: 657-675, Apollodorus 1997: 3:4:1) (Ogden 2013a: 110-111, Ogden 2013b: 147), or Ladon, guardian of the Hesperides' golden apple tree (Pherecydes. F16c, Apollodorus 1997: 2:5:11) (Ogden 2013a: 58, Ogden 2013b: 147). In several cases, the hero paid a dear price for slaying the dragon, such as Apollo himself, who was exiled in various ways, as punishment for Python's death (Parke and Wormell 1956: 11-12, Fontenrose 1980: 326-327, 379-381), or Cadmos, who was tormented all his life for the slaying of the dragon of Ares, and eventually himself turned into a snake, together with his wife (Pausanias 1979: 9:26:2-4, Ovid 1998: 4:536-603, Nonnus 2004: 4:416-420, Ogden 2013b: 52-54).

The dragon image was conceived in the shape of a snake for a long period. Over time, it was elaborated with additional limbs such as wings, fins, and more (Delacampagne and Delacampagne 2003: 26). In Allegory and the Migration of Symbols, Rudolf Wittkower (1987: 16-44) follows the migration of the motif of the fight between the snake/dragon and the eagle, and determines that this is a symbol of a battle between the heaven/sky/upper gods region and the underworld/chthonic gods. The most famous additions to a dragon are wings, which symbolize a 'sky/heavenly' element, which unites the dragon within the realm of the gods in a higher sphere than humans. I contend that this was connected to the rise of the issue of salvation and the elevation of the concept of the soul (Rohde 2010 [first ed. 1925], Alvar 2008). Moreover, I contend that it gave voice to the dichotomy between the body actually being buried underground and the underground realm of the dead and the belief in the rising of the spirit - for example, the Egyptian concept of separation between $\mathrm{Ka}$ (the materialistic manifestation of man) and $B a$ (the spiritual part of the man, represented as a bird that departs from the body when one is dead) (The Man Who Was Tired of Life) (Faulkner 1956: 21-40, Allen 2011: 162-202. Also see: Cumont 1922). But the wings are only one set of features added to the dragon, among many other possibilities.

There are times when the complexity of the definition of the dragon image is challenging: should a monster like the Chimera, which has only minimal reptilian features, be considered a dragon? Ogden (2013b: 5) contends that the Chimera and similar beasts should be considered dragons. I believe that there is no general rule. 
For example, Argos, the many-eyed monster sent by Hera to guard Io, is represented in art as a human-looking monster that has eyes all over its body, but in Homeric literature, Hermes is called Argeiphontes - dragon-slayer - for killing Argos (Chittenden 1948: 24-33, Davis 1953: 36). S. Davis sees Homer's Hermes as a replacement for an ancient god of snake's cult, and recounts in Homer's words an explanation for Argos' snakelike identity.

Figure 1. Argos Painter (5 $5^{\text {th }}$ Century. BCE) Hermes Slaying Argos Panoptes, Sketch of Attic Red Figure Stamnos

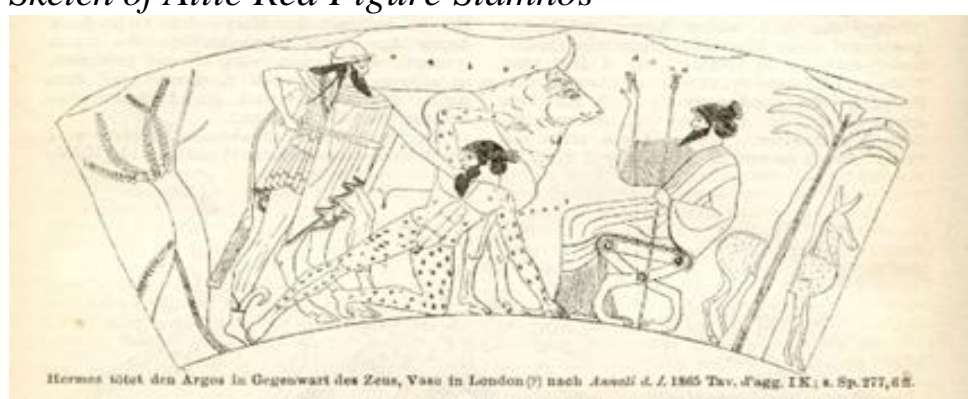

Source: Vienna: Kunsthistoriche Museum. Public Domain via Wikimedia Commons

Another complexity of the dragon image is the hybridization with humans. While portrayals of dragons sometimes include additional limbs from all over the animal kingdom, sometimes they combine the creature with a human form. Although Ogden (2013b: 68-115) does not differentiate between these hybridized depictions from the dragon image, I suggest that in some cases these hybrids should be considered two separate entities that are grotesquely joined.

Figure 2. Python Painter (350-340 bce) Python Painter, Cadmos Combats the Dragon, with Harmonia, Paestan Red Figured Calyx Krater, H. $56.70 x d$. $52.50 \mathrm{~cm}$

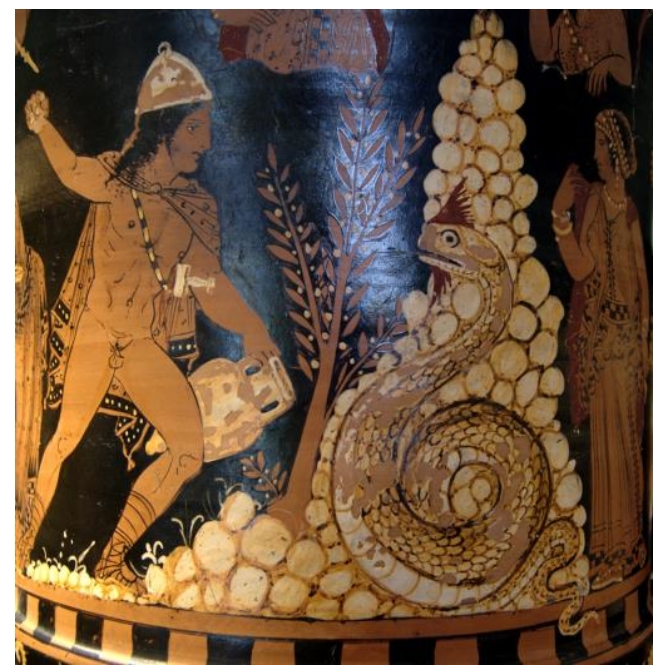

Source: Paris, Louvre Museum. Public Domain via Wikimedia Commons

The first step to a better understanding of the dragon's figure and visualization is noticing its ancient assimilation with and origin in snakes. While literary sources 
use the word 'drakōn', the visual arts depict a serpent (that can be big or tiny). For example, one could consider the persistent iconography of Cadmos confronting the dragon of Ares, or the Athena Giustiniani statue. Therefore, my next subchapter explores the origin of dragons from snakes, and demonstrates that from antiquity to the Early Modern period, 'snakes', 'serpents' and 'dragons' are one and the same word and visual representation.

Figure 3. Copy of Pheidias ( $2^{\text {ed }}$ Century) Athena Giustiniani, Parian Marble Copy of a Bronze Sculpture Dated to Late Fifth-Early Fourth Century BCE, From the Temple Of Minerva Medica on the Esquiline Hill

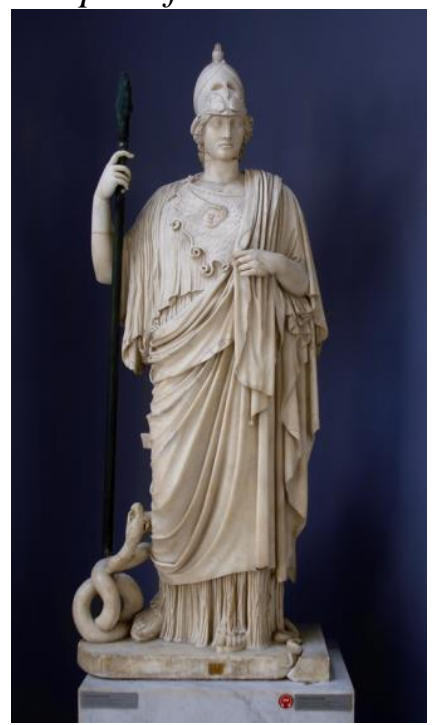

Source: Vatican Vatican Museums. Public Domain via Wikimedia Commons

\section{The Snake Becomes Dragon in Human Conceptions}

The origin and visual meaning of snakes and dragons are the same in ancient cultures - and on to the early modern period. This part of my article explores the biological qualities of snakes, and how they came to be manifested as dragons in antiquity. For this section, I must stress that the twenty-first-century separation between the zoological animal we name snake and the fantastic figure we name dragon did not exist in earlier time.

There are several biological features of the snake that should be identified in order to understand the nature and function of the dragon.

\section{Crawling}

a. The human 'life metaphor' is rooted in our physiognomy, especially our vertical axis, and the fact is that our sensing points, the entryways for air, water and food, and our organs of communication are mostly located in the head. Thus, a basic life metaphor is 'up', associated with 'happy', 'healthy', 'life' and more. The opposite metaphor is 'down', associated 
with 'sadness', 'illness', 'death' and more (Lakoff and Johnson 1980: 1421). The snake is the representation in nature of the absolute opposite of man - it has no limbs and moves horizontally, in the realms of 'down'. This led to identifying the snake figure with all that 'down' symbolizes 'illness', 'death', 'evil' and more.

b. The fact that the snake is located at our 'down' also has a biological implication; human beings are the most vulnerable at their feet, which are the least sensual parts of the body. Thus, the snake's place is at the human's 'Achilles heel' (in real life as well as metaphorically).

c. The snake's crawl is undulating. Its way of advancing creates the notion of a wave moving forward. The symbol of the wave as a zigzagged straight line is known from ancient Egypt, for the hieroglyph for the word water is mam (the phonetic sound for N) (Golan 1991: 101-114). Not surprisingly, the same culture presented the dragon Apophis as a zigzagged line that looks exactly like the hieroglyph.

d. I contend that the shape of the of the snake's movement is the root of the association between the dragon and water.

e. Swimming comes very naturally to a snake; its mode of progression allows it to advance very fast in the water while coordinating its movement to that of the water, which is another reason for the connection between the dragon and the water element.

\section{The Venom}

a. Some snakes are venomous and several have venom so strong that they can kill a fully grown man in an instant. This feature has fascinated human beings from the dawn of time. In ancient Greek, snakes were believed to have a profound knowledge of herbs so that they could concoct a fatal poison (Ogden 2013b: 201-202). This is one of the reasons why snakes were believed to have a higher level of intelligence than man - that is, that they were thought to have access to knowledge of nature that eluded humans

b. The fact that a small snake can, with lightning speed, overcome even the strongest man combined with the snake's chthonic qualities caused humans to believe them to be messengers of the underworld.

\section{Skin Shedding}

a. Another biological phenomenon that caught man's imagination was the fact that a snake leaves its old skin and emerges new and bright. Ancient men considered this as an ability to rejuvenate one and overcome death. The belief that snakes could overcome the absolute destiny of death was intriguing, and it led humans to try ways of imitating the behavior of snakes. Again, ancient Egypt offers the best example, where a dead body 
was wrapped in shrouds in order that the deceased might emerge revived and young in the afterlife (This ceremony was also associated with the caterpillar's cocoon). It is no wonder that Hathor - the goddess that functioned as the metaphoric womb in which the deceased dwelled until being reborn - was the one that transformed herself into the Aureus cobra (Roberts 1995. In other times Wadjet was considered as the cobra, see Lesko 1999: 23, 81-82).

b. The combination of the shedding of the skin and the production of venom caused humans to view the snake as an alchemist that knew how to make potions that could kill but could also heal, whence comes the association between the snake and the notion of healing.

c. Agriculture gods were also perceived as having to do with death and rebirth. The ability of snakes to control death and rebirth speaks to the connection between snakes and agriculture, wherein snakes were worshipped to ensure a good yield (Cook 1940: (1)211-229, Ogden 2013b: 204-205).

\section{Inhabiting Lairs}

a. A snake inhabits an underground lair; sometimes it hibernates in the winter and only comes out in the spring, which simulates the behavior of vegetation. Yulia Ustinova demonstrates a connection between anguipedic deities, which had legs in the form of snake tails, and others that had vegetative legs, proving that the snake and vegetation were equal one to the other (Ustinova 2005: 64-79).

b. Mary Douglas's (1966: 56-57) famous study on holiness and defilement of food in prescientific cultures posits a connection between taboos on food and animal habitations; animals that live underground are considered messengers of the underworld, so are defiled and should not be eaten. Mircea Eliade (1964: 259-266) discusses the role of snakes in shamanic cosmology in regard to the underground realm and the world of the dead. Anthropological evidence indicates that a snake was considered to be a messenger of death.

c. The snake's chthonic qualities connect it to the earth element as well as to vegetation.

\section{Lidless Eyes}

a. Snakes have no eyelids, so they were thought to be sleepless. What is a better guardian of something precious than an animal that has its eye open eternally and is always awake? Therefore, the Aureus cobra was the deity chosen to guard the Pharaohs (Lurker 1980: 125, Roberts 1995: 8, 34), Argos - the thousand-eyed monster - was the guardian for Io (Chittenden 1948: 24-33, Davis 1953: 36), Ladon - the guardian of the Hesperides tree 
with the golden apples - was sometimes described as having a hundred heads, but was depicted with a maximum of two heads in visual representations (Apollodorus 1997 2:5:11) (Ogden 2013a: 58, Ogden 2013b: 37), and so on. The very word drakonn originated from the word derkomai which means 'to see' (Ogden 2013b: 173-178).

\section{Shape}

b. The fact that a snake is shaped as a straight line with no limbs or interrupting features triggered human imagining. First and foremost, the snake was likened to a stick without branches, which associated it with a branchless rod and eventually with a tree. A famous example is the competition between Moses and Aaron and the Pharaoh's priests in which Aaron's rod turned into a snake and then back into a rod (Exod. 7:11-13).

c. The snake's corporal flexibility led humans to imagine a snake as holding its tail in its mouth - creating a perfect geometrical circle. The cosmologies of several cultures depict the world as being surrounded by a huge dragon, which holds his tail in his mouth and keeps all matter together, thus preventing the world from coming apart, for example, the Ouroboros dragon (Graves 1955: 27-28, Reemes 2015). This shape was also linked to the element of time, especially in light of the rim surrounding Aion (Levi 1944: 269-314, Jackson 1985b: 17-45, Beck 1988: 54-57).

d. Another connection to time was the Caduceus/Kerykeion Halm-Tisserant

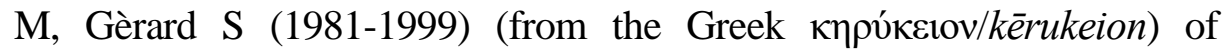
Hermes's Psychopompos sceptre, which has on it one or two dragons shaped as the digit 8, symbolizing eternity and reincarnation. The Caduceus/Kerykeionis mentioned in Cashford 2003 (The Homeric Hymns: Hymn to Hermes, 498) as the dead Python, which Apollo gave Hermes as a gift (Davis 1953: 37, Halm-Tisserant and Siebert 1981-1999: (1.1) 728730, (1.2) 495).

Figure 4. (Originally From Fifth Century BC) Hermes, Marble Statue with Bronze Caduceus, Roman Copy of a Greek Bronze Statue

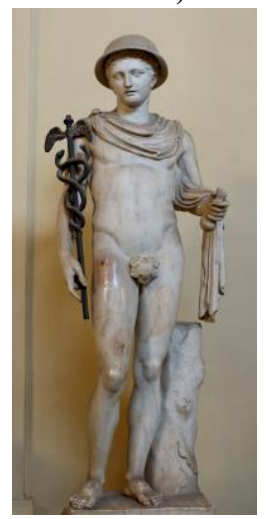

Source: Vatican: Museo Chiaramonti, Vatican Museum. Public Domain via Wikimedia Commons 
e. A unique use of the snake's shape is the image of a snake wrapped around a tree. I suspect that initially, this came from a Greek visualization based on the human figure and modus, which compelled artists to depict the dragon's figure vertically so that it would fit a composition that was based on a vertical modus. Roger Beck likened the spiral movement of the snake around an object as a symbolic visualization of the movement of time.

In dealing with the Mithraic Leontocephaline figure, which has an Aion/ Kronos aspect, in Planetary Gods and Planetary Orders in the Mysteries of Mithras, Beck (1988: 57) showed that the movement of the snake around the body of the god was a geometrical display of two time-systems - the linear and the circular. This was, then, a philosophical representation of the snake figuring the process of the soul from life to death and back (reincarnation), so it also symbolized the annual agricultural cycle as well as linear progress toward salvation. All of this is associated with the rise of the value of redemption and salvation religions (Alvar 2008).

Figure 5. Scheme of the Movement of the Dragon

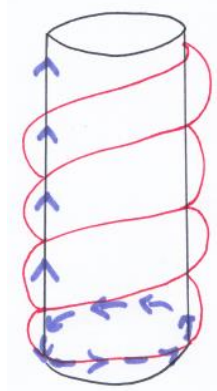

Source: Inspired from a sketch from (Beck 1988: 57)

f. From the first to second century CE, the image of an encircled dragon was a visual symbol of the shrines of Osiris (Kater-Sibbes, 1973: 151, Cat. 802).

Taking into account all these biological qualities of the snake and their ancient interpretations led to a dragon image that manifested an opposition to man, that was considered more intelligent than man, and that had access to profound knowledge, which man craved. These features resulted in a symbolic connection between the dragon and water, earth, and agriculture. Associating the dragon as a guardian with agriculture yielded many myths wherein the creature was often a guardian of a tree or a water source. Most fundamentally, the dragon was a messenger of the underworld, which is what Claude Levi-Strauss (1963-1983, 1999: 25-33) defines as a 'trickster' - a being that has the ability to move and mediate between worlds. The dragon is a trickster of time, space, and matter. 


\section{Prototypes of the Dragon in the West}

My research indicates that there were four prototypes of dragons in the Mediterranean region. I distinguish one group from another, but there is a measure of fluidity from one prototype to the other. The separation is meant to create a classification system, which I find very useful.

a. The Python - This is the basic dragon type that is credited with being a strong adversary with magical powers, its magician-like qualities usually being manifested after the dragon's death. The Python dragon is associated with a cave and a river. It is sometimes portrayed with wings because it belongs to a sphere closer to the gods. Examples: Apophis, Python, the Thebes dragon of Mars, and Mot (king of death).

b. The Hydra - This is the cosmic dragon that is sometimes multi-headed. This group also includes Ouroboros-like dragons, which are usually the symbol of the ultimate Doomsday battle between order and chaos (AyaliDarshan, 2011). The Hydra also represents the cosmic contraries relationship between heaven and the underworld. Examples: Hydra, Typhon, Ouroboros, the Zoroastrian Aži Dahāka and Thraētaona/ Zohak dahāg, the Antichrist dragon (Rev. 12: 7-9), the Old Testament's 'TohuVavohu' (Gen. 1:1), the last of which, according to the scholars mentioned above is a dragon as such it belongs to this type, for it preceded god (Forsyth, 1987: 95).

c. The Ladon - This is the dragon that is wrapped around a tree or another vertical object. It is usually connected to beneficial aspects, medicine and healing, and to the concepts of time and circularity. This type is in most cases the guardian of a treasure - mostly trees and fruits and is connected to fertility concepts. Examples: the serpent of Colchis, Ladon, Asclepius and Salus/Hygieia dragons, the serpent of Eden (Gen. 3:1-26), the dragon that is wrapped around the Mithraic Leontocephaline, Humbaba, Aureus, Azag, and others.

d. The Ketos - This is the sea dragon, which is connected to water and the chaotic behavior of rivers and oceans. Examples: Ketos, Yam, Leviathan, Charybdis, and others.

As noted above, although this separation helps to schematize the dragons into specific rubrics, there are many cases in which a particular dragon can fit with more than one category. For example, the huge snake from the ancient Egyptian story of 'The Tale of the Shipwrecked Sailor' (Lichtheim 1973: 211215, Baines 1990: 62) seems to be a Python type at the beginning of the story when it rescues the terrified sailor. However, as the tale continues, it becomes clear that the snake-dragon existed prior to the beginning of the world and was one of the most ancient gods that was banished; which labels him as a Hydra type, owing to his Ouroboric nature.

One of the principal interests regarding dragons is the 'dragon-slayer' topos - the adversarial relationship between a king or a god and a creature that 
represents the deserte (the desert place - where man is not) and death (Barasch 2000: 153-172). Fontenrose (1980: 146-272) and Watkins (2001: 297-518) demonstrate how these myths were conveyed from Mesopotamian and IndoEuropean cultures to Greece and were embellished in a Greek-like manner. Carl Jung (1919: 401-422) viewed the dragon-slayer topos as a fundamental pattern imprinted on the human subconscious and as the climax of the journey for the 'hero' archetype. Nonetheless, we must regard this notion with caution because there is little evidence of that topos anywhere except in Europe, parts of Asia, and Africa. Even China has a fundamentally different approach toward the dragon, which is why I am focusing here on the Mediterranean region and specifically on Greco-Roman cultures.

Northrop Frey (1982, 1990, 2006, 2014, 2016, Denham 2012) contended that the dragon fight topos from the Hebrew Bible and the New Testament portray the basic archetype unit for literary analysis. Adding to Robyn Cadwallader's (2008: 17-26) criticism, I agree with her that particularly St. Margaret's story - but not only - prove to be alternative narrative structures. And again, the Judeo-Christian bio of the dragon is irrelevant these days. Furthermore, I contend that the artistic evidence provides an even more elaborate and conflicting notion of the dragon's symbolic meanings.

\section{The Dragon Figure in Greco-Roman and Christian Cultures}

Daremberg (1877-1904: 403-414) was the first to demonstrate that dragons in Greek and Rome were both good and bad. For example, Agathos Daimon, the benevolent protecting spirit was imaged as a serpent (Bonner 1950: 142, 162, 169, Toynbee 1973: 224, Dunand 1981-1999: (1.1) 277-282, (1.2)203-207, Alvar 2008: 58-59, Ogden 2013b: 297-309), and Oikouros/Ophis was the apotropaic serpent of Athens (Herodotus 2008: 8:4)(Ogden 2013b: 203). I believe that the popularity of the dragon figure climaxed in the Roman imperial period. Ichnographically, almost none of the contemporary portrayals of dragon-slaying depicted the actual combat; rather, the hero was usually represented after his victory. In Rome, the dragon was worshipped and presumed to embody the genius paterfamilias (Toynbee 1973: 233). Thus, I suspect that confronting a dragon in battle gradually began to be perceived as blasphemy, and therefore the battle against it was left out of artistic representations, although such references were still included in the literature.

This awe of the dragon was probably the reason that Christianity adopted that figure to symbolize the ultimate enemy (Delacampagne and Delacampagne 2003: 133-134), and described the Antichrist in the form of a dragon (Rev. 12:7-9). The myth of the ultimate combat on Doomsday was rooted on the dragon-slayer topos found in such myths as Zeus combating Python, the Zoroastrian Ahura Mazda combating Aži Dahāka, and Zohak Dahāg, the Ahriman dragons (Ogden 2013b: 13). Christianity embraced this topos and flattened the figure of the dragon negating all of the creature's benevolent qualities (Lippincott 1981: 2-24, HeinzMohr 1982: 143-145, Levi D'Ancona 2001: 120-123, 144), while dismissing all 
snake cults and the dragon's many magical attributes. The serpent of Eden, which whispered to Eve the fears of God himself (Gen. 3:1-6) (Johnston 2000), was considered in Christianity as Satan who initiated the Eden deadly sin that Christ's death abolished (Romans 5:12-21, Corinthians 15:21-22) (Forsyth 1987: 419-440, Lander 1995: 73-77, Wallace and Rusk 2010). Bonner (1950) focused on Gnostic magical amulets, presenting alternative Christian approaches toward dragons in Christian cultures; as soon as the Gnostics denomination was declared heretic, the idea of the apotropaic dragon fell into even more disfavor (Forsyth 1987: 221247). Thus, in mainstream Christian theology the dragon is analogous to the devil (I challenge this determination in a different study I conduct on St. Margaret). Folktales continued the legacy of the dragon-slayers topos in lore (Fontenrose, 1980: 521-544, Evans 1985: 85-112). Stories such as that of St. Simeon Stylites, which had a dragon seeing the truth of God, are exceptional as it refutes the belief in the inability of dragons to see the light because they symbolized ultimate darkness (This hagiography of St. Simeon Stylites was written by Father Antony much later than the period of the saint's life: Migne JP (ed.) (1996). 73:330AB: The Tempta Flaubert G (trans) (1910) tion of Saint Antony) (Elliott 1987: 157, Rowland 1975: 69).

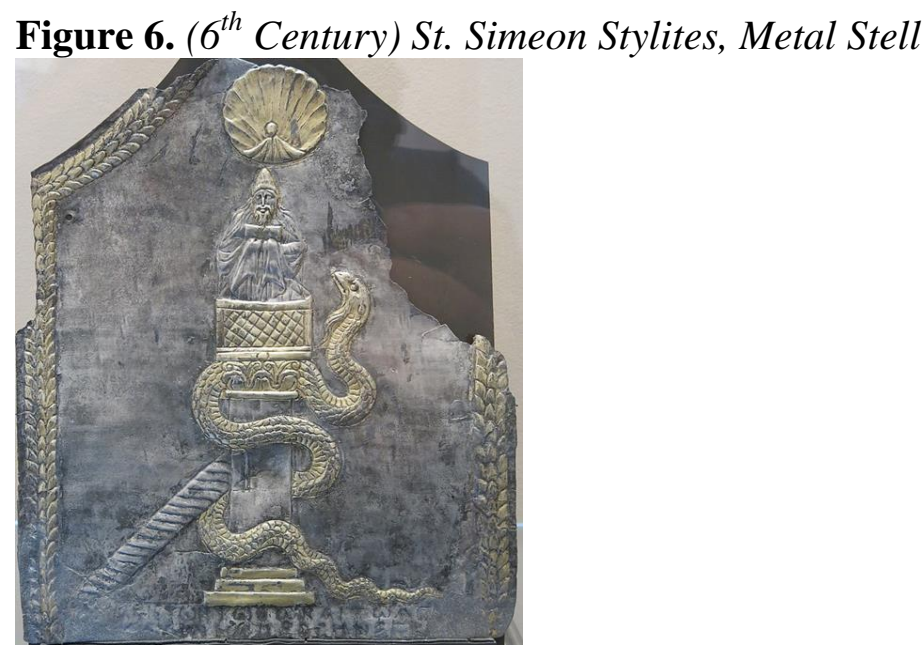

Source: Paris: Louvre - Salle de Qabr Hiram. Public Domain via Wikimedia Commons

St. Antony's life as depicted by Antonius of Alexandria (296/8-373 CE; Gregg $R C$ (trans and intro) (1980)) includes descriptions of several dragons as well as other monsters as being among the wild animals that were defeated by the saint's faith when he lived in the wilderness (Gregg RC (trans and intro) (1980). 6:34-35, and 28:52-53). The wilderness and the wild beasts depicted in that hagiography serve as evidence of the fear of what might be lurking outside the city. They also stand as an allegory that demonstrates the triumph of the human soul over the suffering of the flesh. The theme of the dragon as habituating the wilderness flourished in Europe (Barasch 2000: 153-172), for example, every mappa mundi showed the dragon as the symbol of the desert - a term that refers to every location that was conceptualized as deserted by advanced civilizations. In the eyes of ancient and medieval European cultures, this included China and South 
Africa (Non-European civilizations were perceived by European cultures of that time as the 'ends of the world' and as deserted and grotesque) (Bane 2016: 7).

I must note at this point that whereas in Greek culture, the dragon was always the hero's adversary, in Egypt a dual attitude toward dragons was more common, particularly when addressing the protective cobra Wadjet (Troy 1986: 115-125, Roberts 1995: 75-78, Lesko 1999: 64-80). I believe a tale of a hero's positive encounter with a dragon comes from a notion in the ancient Egyptian culture, which inspired the dragon meaning among the Gnostics, where the snake of Eden was considered a prefiguration of Christ. The Gnostics believed that Christ was crucified by the false god Yaldabaot (Jehovah) and that Eden snake was a prime being that granted profound knowledge to man, thus prefiguring Jesus, who gave true knowledge to mankind (Kripal 2007). That being said, Yaldabaot has several dragons among his seven principal assistants (Jackson 1985a: 31-33). In any event, Gnosticism was a heretical cult and was eventually suppressed.

On early Christian sarcophagi, we repeatedly encounter the iconographical scheme of Jonah being swallowed by the big fish - imaged as a Ketos dragon. Jonah is also depicted as emerging out of the Ketos's mouth to salvation (Boardman 1987: 73-84, Narkiss 1978: 63-76, Noegel 2015: 236-260).

Figure 7. (Third Quarter of the $3^{\text {rd }}$ Century) Jonah Sarcophagus, Marble, Approx.

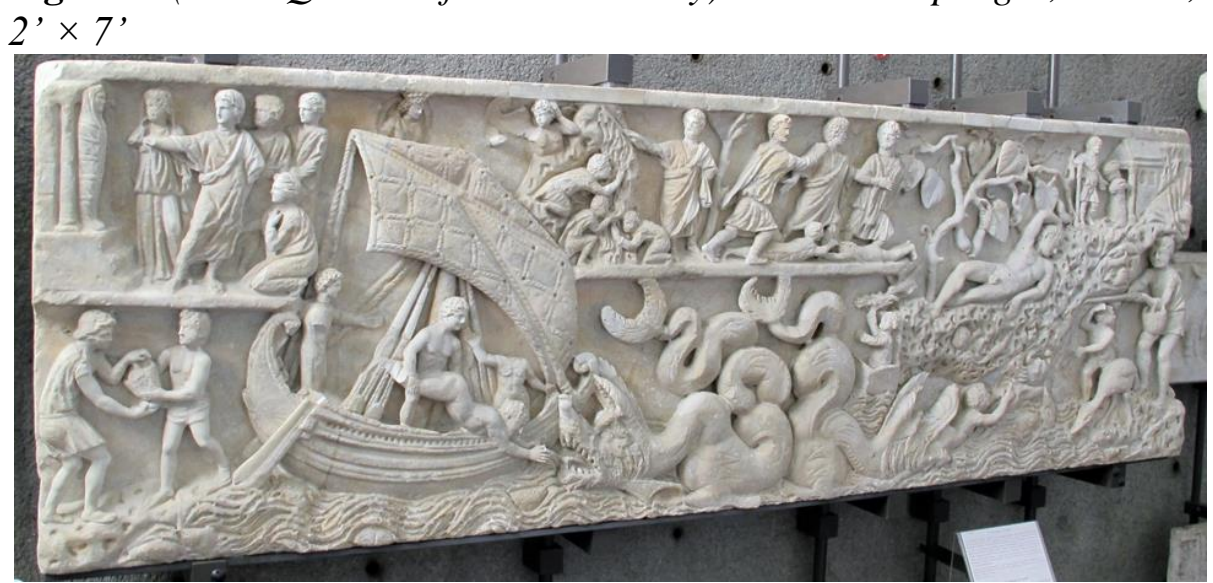

Source: Vatican: Museo Pio Cristiano (inventory 31448). Public Domain via Wikimedia Commons

This iconographic type is consistent with the ancient Greek story of Hercules being swallowed by a dragon, when he tried to save Hesione (Apollodorus 1997: 2:5:9).

Early Christian images of Jonah were also inspired by the iconography of Jason's vase, which depicts the hero emerging from the dragon's mouth. 
Figure 8. Douris Cup (480-470 BCE) Jason, From Cerveteri (Etruria)

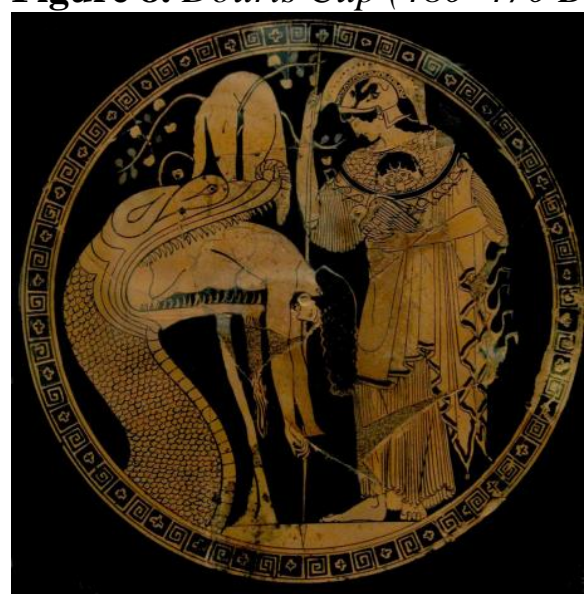

Source: Vatican: Vatican museum - Museo GregorianoEtrusco. Public Domain via Wikimedia Commons

In Christianity, the body of the dragon symbolizes the underworld and is the emblem of purgatory. Jonah, in early Christianity, was the prefiguration of Jesus, and the narrative of his being swallowed by the whale foreshadowed Jesus's death and rebirth as well as his descending to Hell (Luke. 16:23, Pet. 3:18-20). These notions inspired medieval Western iconographers to image purgatory as a dragon's open jaw, for example, Hell as represented in the 'Book of Hours of Catherine of Cleves' (Turner 1993, Wieck 1997: 66-70).

Figure 9. Master of Catherine (C. 1440) Hell, Book of Hours of Catherine of Cleves

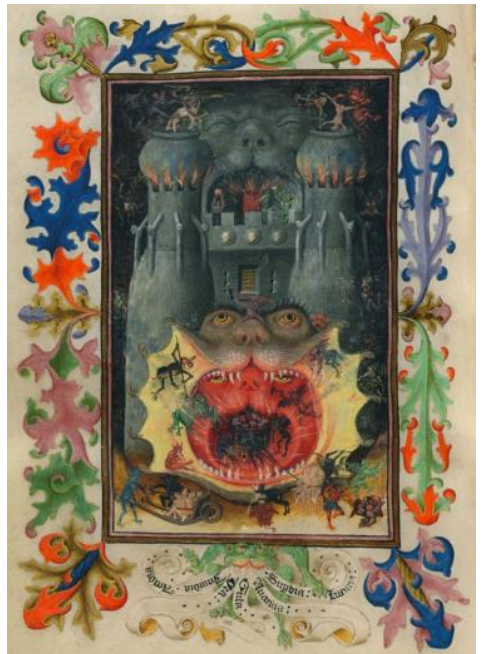

Source: Utrecht: The Netherlands (MS M.945, FOL.168v). Public Domain via Wikimedia Commons

The dragon-slayer theme was adopted into Christianity at a very early period. The description of the Archangel Michael battling the Antichrist imaged as a dragon (Rev. 20:2), which was prefigured by the Small Apocalypse described in Isaiah 27:1, and in Job 26: 5-14. All of these are reflections of the topos of the 
Egyptian and Zoroastrian concept of the ultimate cosmic combat between the allgood solar god and the primeval chaotic evil dragon, which was to lead to global salvation. On the other hand, there are depictions of a mortal fighting a dragon, which reflect the good king propaganda's image that I described earlier. For example, Eusebius's (1999) description of Constantine as a dragon-slayer in a monumental painting in the front of his palace (Life of Constantine. 3.3. 1-3) and the late antique descriptions of King Solomon as a dragon-slayer, represent the flesh-and-blood continuation of the dragon-slayer topos and its adaptation into Christianity (Walter 1989: 659-673). Christ himself was considered a dragonslayer. Various dragon-slayer saints, including St. Sisinnius and St. Theodore (Pancaroğlu, 2004: 151-164), among others (Ogden 2013a: 196-246, Ogden 2013b: 385-399), are known in Byzantine, and the topos of the dragon-slayer emerges again in Western Europe in the addition to the hagiography of St. George (Jacobus de Voragine (1993): Readings on the Saints, 58), where he was depicted as combating a dragon. (The first evidence of the 'dragon-slayer' narrative of St. George dates from the twelfth century. Aufhauser 1911: 237, Mark-Weiner 1983, Bulletin of the Art Institute of Chicago 1922: 18-21, Kaftal 1952-1985: 443-446, 649-658, Balboni 1961-1970: 512-525, Sotomayor 1961-1970: 525-545, Fontenrose 1980: 515-520, Heinz-Mohr 1982: 143-145, Didi-Huberman 1994, Maré 2006: 195-203, Morabito 2011: 135-153).

The early Medieval iconography of the dragon-slayer originated in the scheme from Ravenna of Christus Victor - trampling on a snake and a lion - a depiction that follows the description of the victorious God trampling on a snake and a lion, as described in the Old Testament (Ps. 91:13).

Figure 10. (Late Fifth or Early Sixth Century) Christus Victor, Mosaic

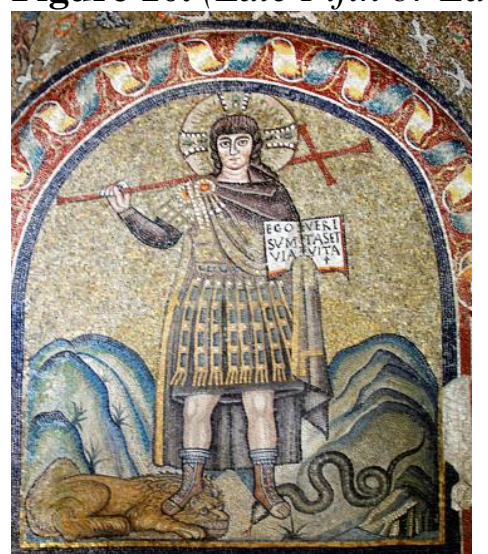

Source: Ravenna: Chapel of the Archbishop. Public Domain via Wikimedia Commons

From that point on, when presenting a situation of a dispatched dragon, artists depicted the human-like figure as standing erect on a horizontal dragon image; usually, the dragon was shown after being conquered. I stress this to suggest that the point in the narrative that was chosen in medieval Europe was usually the moment after the dragon was defeated and overpowered.

An unusual representation of the medieval dragon is to be found in the Eden' myth, the only iconography in which the dragon is portrayed as being powerful - 
at least in the first part of the narrative. In the scene in which He punishes the serpent/dragon, God is not portrayed as trampling on the dragon (Jones 1981, Lander 1995: 73-77, Bartal 2009: 37-61, 77-101, Arbel 2012).

Figure 11. (1007-1015) Detail: Adam and Eve, the Bronze Doors of the Hildesheim Cathedral, Commissioned by Bishop Bernward of Hildesheim

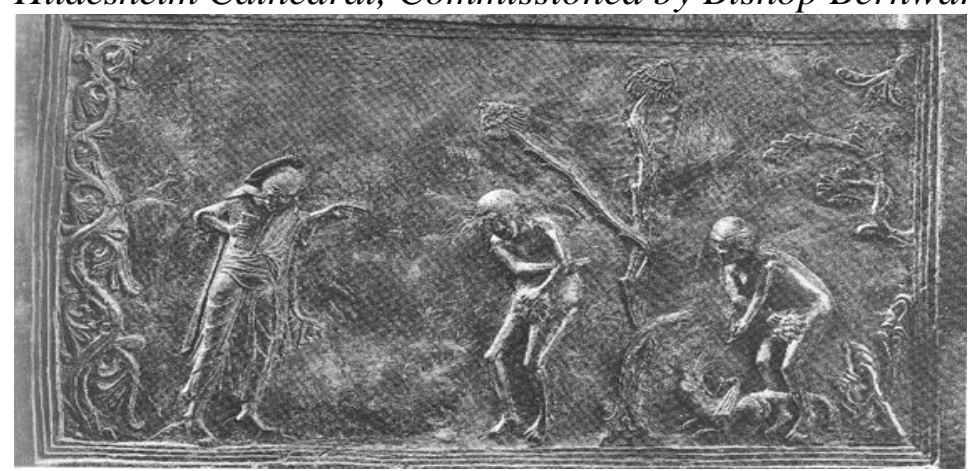

Source: Hildesheim: Hildesheim Cathedral. Public Domain via Wikimedia Commons

This Eden scene was inspired by Mystery plays that used to portray Satan in the Eden narrative as a very strong and colorful figure, which has the potential to overcome every human being (Bonnell 1917: 255-291).

St. George's position was well established in early modern Italy, and he was among the most important of the Venetian and Florentine saints. A detailed description of the festivals of St. George was circulated in Venice, when commemorative equestrian tournaments that were held to enhance the connection between the Italian knighthood culture (Armstrong 1897: 552-555) and St. George (Eisler 1989: 220, Ciseri 2013: 131-149, Butterworth 2013: 318-342). In Florence, a St. George scene decorated the city's gate from the eleventh century. That gate was lost in a flood, but the Florentines continued believing that St. George was still protecting the city for centuries after the gate was destroyed (Ciseri 2013: 132). Both St. George and Archangel Michael were often depicted, along with their dragons, during the fourteenth to the seventeenth-century evolving art of Italy.

\section{The Dragon Figure in Medieval and Early Modern}

Greco-Roman myths endured throughout the Middle Ages, especially Ovid's Metamorphoses. The dragon-slayer myth of Apollo and Python was subject to many theological interpretations: Apollo was considered as a symbol of Jesus, truth, light, good, and life, whereas Python was perceived as a representative of deceit, darkness, evil, and chaos (Barnard 1987: 70-81). The same myth received an entirely different interpretation by the Benedictine Pierre Bersuiras, wherein Apollo is presented as an evil being that destroys the sun and the Python is the good creature that protects man from Apollo's savage arrows. These theological interpretations prove that the opposing symbolic meanings of the dragon endured over time. Mary E. Barnard also elaborates the 
connection between the description of Python by Bersuiras and the one by Francesco Petrarch's in Africa (3:157-73) of the three-headed dragon, which was both inspired by Macrobius's 'Saturnalia' (Barnard 1987: 71).

The figure of the dragon was very popular on arms during the medieval and early modern periods (Nickel 1989: 25-34). The sign of the Draco' platoon - an army unit from the Roman era - adhered to the dragon's apotropaic interpretation (Topsell 1608. 154) (South 1981).

Figure 13. (Mid-2 $2^{\text {nd }}$ Century CE) Draco and Other War Trophies, Marble Relief



Source: Rome: Hadrianeum. Public Domain via Wikimedia Commons

Stephen R. Wilk (2000: 42) translates the word 'apotropaic' as "to turn away" and relates to this subject when discussing the well-known Gorgon's head as an apotropaic device, a well-known example being the image portrayed on Athena's shield in the Parthenon Temple, sculptured by Phidias (Leeming 2013: 45). The apotropaic function of the dragon image continued in the medieval period, for example, in the phenomenon where monsters were figured all over the outer walls of a church in order to prevent demons from entering (Benton, 1996: 147-165). The dragon's apotropaic nature was most articulately described in the story of the copper snake as told in Numbers 21: 6-9, where the Israelites encounter a place overrun with snakes and God tells Moses to create a copper statue of a snake, which would protect whoever looks at it. This is a perfect example of recruiting the image of the enemy as an ally. This episode was adopted into Christianity as early as the time of the apostles (John 3:14) as the emblem of Christ. The connection between the copper serpent and Christ is the reason that the image of Jesus on the cross is in an ' $\mathrm{S}$ ' shape that resembles a snake (Kessler 2009: 119134).

In books on astronomy, from ancient Greece on, there are many depictions of the constellation of Ketos, which image the myth of Perseus and Andromeda (Phillips 1968: 22-23, Boardman 1981-1999: (8.1) 731-736, (8.2) 496-501, Wilk 2000: 129-143; Ogden 2013a: 163-165: source: 109). Guido Bonatti referred to the constellation Draco in Tractatusastronomie (f. $26 \mathrm{v}$ ) contending that the body of that dragon contains the contraries 'good and bad' within itself. (Pedretti and 
Roberts 1984-1986: 72, Caiozzo 2009: 419-427, Ogden 2013b: 38, 85, 164-165).

Belief in the existence of dragons held sway up until the seventeenth century. In fact, a good deal of apparently undisputed evidence was offered for the existence of dragons, and there was apparently never any doubt (Although these days dragons are considered fictional, we see that some still bother the human imagination, e.g., Loch Ness monster. In fact, there is a television program on the very respectable 'National Geographic' TV channel called 'Monster Quest,' which investigates evidence of the existence of monsters). In Severo and the SeaMonsters, Bernice F. Davidson (1997: 23-25) presents a number of documented testimonies proving the existence of monsters. Aristotle (2012) and Pliny the Elder 1958-1966: 8:11-15, 9:4) both testified to the existence of dragons. These volumes were followed by bestiaries, theologies, and by both true and fictional travelogues, including the well-known volume by John Mandeville (1983). There are also many dragon illustrations in the Marco Polo's (1254-1323) memoirs. We can understand that the actual traveler could only describe what he has seen in words, but the draftsman's imagination and perception of the location of dragons led him to depict many animals as species of dragons (Delacampagne and Delacampagne 2013: 57-74).

Figure 14. (1254-1323) the Book of Ser Marco Polo, the Venetian, Book Illustration, Livre Des Merveilles: Fol. 55v

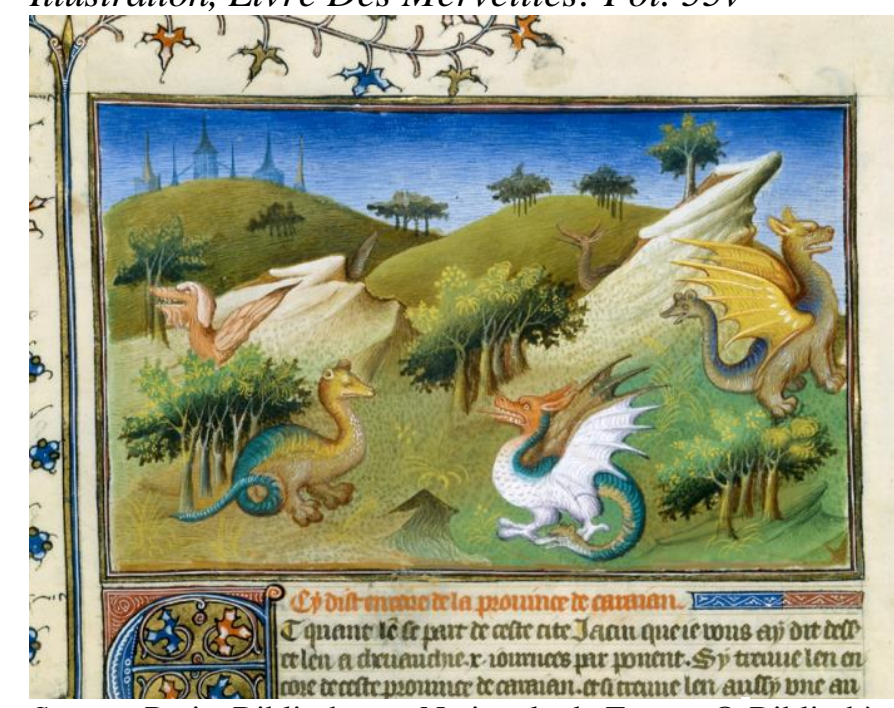

Source: Paris: Bibliotheque Nationale de France.@ Bibliothèque nationale de France

Petrarch continued this tradition in his description of Africa (Africa 3:15773). Davidson (1997: 23) points out an important aspect concerning dragons, that is, that at one point in time there actually were dragons, creatures that are known today as dinosaurs! Davidson refers to Pliny's documentation (Natural History. 9:4) from ancient Rome, where a complete skeleton of "the monster to which Andromeda in the story was exposed" was exhibited in the centre of Rome for all to see. Pliny described the skeleton's dimension as $40 \mathrm{ft}$. long and the ribs set higher than an elephant's, and wrote that it was brought from Jaffa by Marcus Scaurus. All of these details probably described a complete skeleton of either a 
whale or a dinosaur, and provided decisive proof for a belief in the existence of dragons (Ogden 2013b: 116-118). Nonetheless, Davidson (1997: 24-25) noted many manipulations with evidence over time, for example, the alleged mermaid skeleton from the Medici collection.

Another aspect of the dragon figure and meaning arises from the psychoanalytical theory of Carl G. Jung (1919: 401-422), concerning social archetypes. Jung and his disciple Erich Neumann (1954) outlined a linear study of numerous literal and visual sources of several near and Far East ancient cultures. As a result, they claimed that abstract images, which are common to all humans, exist at the very basis of the human psyche. They contended that these elements of the psyche manifest themselves in images, which Jung called 'archetypes' because they are present in all humans. Neumann described a stage-like structure for the psyche, the first stage being the unconscious, which is exemplified by the image of the Ouroboros dragon - a dark omnisexual being that informs the basic level of the unconscious, from which emerges the Big Mother - a higher stage of unconsciousness. The Big Mother symbolizes the ultimate fertilizer and harvester, good and evil, and is paired with the phallus - the child - which is also represented in a serpentine figure. The struggle to achieve consciousness and awareness is manifested in a dragon-slayer formation, where one fights with oneself to be free of the fundamental attachment to the Big Mother, which Jung and Neumann perceive as the treasure awarded to the hero in the dragon-slayer topos.

My present study does not pretend to provide criticism of this psychology theory. Nonetheless, the evidence Jung and Neumann outlined hint at their fundamental awareness of ancient cultures, particularly Mediterranean cultures, for the importance and popularity of dragon images and their various meanins, and the dragon-slayer topos importance.

\section{Conclusion}

To conclude, I partly agree with the Jungian point of view and contend that dragons are a very vivid part of human collective psychology. It constitutes an image that emblemizes all fears and past failures and represents what we, as humans, believe ourselves not to be. In this article, I outlined the way the biological features and qualities of snakes, as opposed to the human structure, resulted in the figure and lead to beliefs that made the image of dragons and their symbolic meanings.

The dragon is an active symbol, which endured throughout the middle Ages, Early Modernity, and is still relevant and vivid in Modern times. It is constantly remodeled and changed throughout all human cultures, with many aspects and symbols attached to it.

This article follows the constitution of the dragon figure in images and literature, and suspects it to be a result of the life metaphor of snakes that are oppositely different from humans. Furthermore, this article outlined several basic steps and issues that constitute the dragon throughout Mediterranean civilizations from antiquity to early modernity. The dragon figure has so much more depth and 
ramifications yet, but this article aims at summarizing only the basic, most influential structure. Up to now, Early Modern lexicons descriptions analysed the dragon figure as one-dimensioned, this article was written to provide several explanations and interpretations for the dragon figure, which grants dragon's descriptions in the Early Modern period some more layers of interpretation, and diversity.

\section{References}

Aristotle (2012) History of Animals: In Ten Books. R Cresswell (trans) Oxford: St. John's College.

Apollodorus (1997) The Library of Greek Mythology. R Hard (trans, intro and notes) Oxford: Oxford University Press.

Bonatti Guido (1506) Tractatus astronomie. Venice: Melchior Sessa.

Cashford J, Richardson N (2003) The Homeric Hymns. (intro and notes) (trans).London and New York: Penguin Books.

Edelstein EJ, Edelstein L (eds) (1998) Asclepius: collection and interpretation of the testimonies. GB. Ferngren (intro) Baltimore, Md: Johns Hopkins University Press.

Euripides (1994) Phoenissae. DJ Mastronarde (ed. intro and comm). Cambridge, Eng: Cambridge University Press.

Eusebius Bishop of Caesarea (1999) Life of Constantine. A Cameron, SG Hal (intro, trans and comm) Oxford: Oxford University Press.

Flaubert G (trans) (1910) The Temptation of Saint Antony. London: Greening.

Gregg RC (trans and intro) (1980) The Life and Affairs of our Holy Father Antony. Mahwah, NJ: Paulist Press.

Herodotus (2008) The Histories. R Waterfield (trans) C Dewald (intro and notes) Oxford, New York: Oxford University Press.

Jacobus de Voragine (1993) The Golden Legend: Readings on the Saints. WG Ryan (trans) Princeton, NJ: Princeton University Press.

Mandeville J (1983) The Travels of Sir John Mandeville. CWRD Moseley (trans and intro) Harmondsworth, Middlesex, En, New York: Penguin Books.

Nonnus (2004) Dionysiaca. WHD Rouse (trans) HJ Rose (intro and notes) LR Lind (notes) Cambridge, Mass: Harvard University Press.

Marco Polo (1254-1323) The Book of Ser Marco Polo, the Venetian. Paris: Bibliotheque Nationale de France.

Migne JP (ed.) (1996) Patrologia Latina. Ann Arbor, MI: Chadwyck-Healey.

Ovid (1998) Metamorphoses. A. D. Melville (trans) Oxford and New York: Oxford University Press.

Pausanias (1979) Guide to Greece. Peter Levi (trans) Harmondsworth, Eng.: Penguin.

Pliny the Elder (1958-1966) Natural History. H Rackham (trans) London: W. Heinemann.

Saint George Combating the Dragon (1922). Bulletin of the Art Institute of Chicago (19071951) 16 (2): 18-21.

Snell B (ed.) (1971-2004) Tragicorum Graecorum fragmenta (TrGF). Goettingen: Vandenhoeck and Ruprecht.

Topsell E (1608) The Historie of Serpents. London: William Jaggard.

Allen JP (2011) The Debate between a Man and His Soul. Leiden, Boston: Brill.

Alvar J (2008) Romanising Oriental Gods: Myth, Salvation and Ethics in the Cults of Cybele, Isis and Mithras. Leiden, Boston: Brill.

Arbel VD (2012) Forming Femininity in Antiquity: Eve, Gender, and Ideologies in the 
Greek Life of Adam and Eve. New York: Oxford University Press.

Armstrong E (1897) La dignità cavalleresca nel comune di Firenze by Gaetano Salvemini [The knightly dignity in the city of Florence by Gaetano Salvemini]. The English Historical Review 12 (47), 552-555.

Aufhauser JB (1911) Das Drachenwunder des heiligen Georg. Leipzig: Druck von BG Teubner.

Ayali-Darshan N (2011) The Diffusion of the Story of Combat between the Storm-God and the Sea in the Ancient Near East: Sources, Traditions and History. Jerusalem: Magnes Press.

Baines J (1990) Interpreting the Story of the Shipwrecked Sailor. The Journal of Egyptian Archaeology 76, 55-72.

Balboni D (1961-1970) Giorgio: Santo, Martire. In Bibliotheca Sanctorum. Rome: Istituto Giovanni xxii Della Pontificia Universita Lateranense, (6) 512-525.

Bane T (2016) Encyclopedia of Beasts and Monsters in Myth, Legend and Folklore. Jefferson, NC: McFarland

Barasch M (2000) The Hermit in the Desert: An Image of Solitude. In A Assmann (ed.) Einsamkeit / hrsg. von Aleida und Jan Assmann. München: Fink, 153-172.

Barnard ME (1987) The Myth of Apollo and Daphne from Ovid to Quevedo: Love, Agon, and the Grotesque. Durham, NC: Duke University Press.

Bartal R (2009) Earthly Love-Divine Love. Jerusalem: Magnes Press (trans from Hebrew).

Batto BF (1992) Slaying the Dragon: Mythmaking in the Biblical Tradition. Louisville, KY: Westminster/John Knox Press.

Beck R (1988) Planetary Gods and Planetary Orders in the Mysteries of Mithras. Leiden, New York: København and Köln.

Benton JR (1996) Gargoyles: Animal Imagery and Artistic Individuality in Medieval Art. In NC Flores (ed.) Animals in the Middle Ages: A Book of Essays. New York: Garland Publishers: 147-165.

Blust R (2000) The Origin of Dragons. Anthropos 95 (2): 519-536.

Boardman J (1987) 'Very Like a Whale' - Classical Sea Monsters. In AE Farkas, PO Harper, EB Harrison (eds) Monsters and Demons in the Ancient and Medieval World. Mainz, Rhine: Verlag Philipp Von Zabern, 73-84.

Boardman J (1981-1999) Ketos. In Lexicon iconographicum mythologiae classicae (LIMC). Zurich: Artemis Verlag, (8.1) 731-736, (8.2): 496-501

Bonfiglioli C (2008) The Snake Symbolism in Rarámuri Dances: An Analytical Bridge Between the Northwest Mexico and the Southwest of the United States. In N Bennahum (ed.) Continuing Dance Culture Dialogues: Southwest Borders and Beyond. New York: Produced at the Print Center, Inc., 34-41.

Bonfiglioli C, Gutiérrez A, Olavarría ME (2004) De la violencia mítica al «mundo flor». Transformaciones de la Semana Santa en el Norte de México. Journalde la société des américanistes 90 (1): 57-91.

Bonnell JK (1917) The Serpent with a Human Head in Art and in Mystery Play. American Journal of Archaeology 21 (3): 255-291.

Bonner C (1950) Studies in Magical Amulets: Chiefly Graeco-Egyptian. London: Oxford.

Butterworth P (2013) Late Medieval Performing Dragons. The Yearbook of English Studies 43 (Early English Drama): 318-342.

Cadwallader R (2008) Three Methods for Reading the Thirteenth-Century Seinte Marherete: Archetypal, Semiotic, and Deconstructionist. Lewiston, NY: Edwin Mellen Press.

Caiozzo A (2009) Autour des dragons célestes: Astronomie, astrologie, magie et imaginaire en Orient médiéval. In T Honegger, C Fanfan (eds) Good Dragons Are Rare: An Inquiry Into Literary Dragons East and West. Frankfurt am Main, New 
York: P. Lang: 419-427.

Chittenden J (1948) Diaktoros Argeiphontes. American Journal of Archaeology 52 (1): 24-33.

Christopher WJ (2005) The Augustinian Epic, Petrarch to Milton. Ann Arbor: University of Michigan Press.

Ciseri I (2013) From the Pagan Idol to Donatello's "Bronze Horse": The Iconography of Condottieri in Florentine Sculpture in the Early 15th Century. In BP Strozzi, M Bormand (eds) The Springtime of the Renaissance: Sculpture and the Arts in Florence 1400-60. Florence: Mandragora, 131-149.

Cook AB (1914-1940) Zeus. Cambridge, UK: The University Press.

Cumont F (1922) After Life in Roman Paganism: Lectures Delivered at Yale University on the Silliman Foundation. New York, New Haven: Yale University Press.

Daremberg C (1877-1904) Dictionnaire des Antiquitès Grecques et Romaines. Paris: Hachette.

Davidson BF (1997) Severo and the Sea-Monsters. (intro) C Ryskamp, (technical note) RE Stone. New York: The Frick Collection.

Davis S (1953) Argeiphontes in Homer - The Dragon-Slayer. Greece and Rome 22 (64): 33-38.

Delacampagne A, Delacampagne C (2003) Here Be Dragons. Princeton, NJ: Princeton University Press.

Denham RD (ed.) (2012) Collected Works of Northrop Frye. Toronto: University of Toronto Press.

Didi-Huberman G, Garbetta R, Morgaine M (1994) Saint Georges et le dragon: versions d'une legend. Paris: Adam Biro.

Douglas M (1966) Purity and Danger: An Analysis of Concepts of Pollution and Taboo. London: Routledge \& Kegan Paul.

Dunand F (1981-1999) Agathodaimon. In Lexicon iconographicum mythologiae classicae (LIMC). Zurich: Artemis Verlag, (1.1) 277-282, (1.2) 203-207.

Eisler CT (1989) The Genius of Jacopo Bellini. New York: HN Abrams.

Eliade M (1964) Shamanism :Archaic Techniques of Ecstasy. (trans) WR Trask. London: Routledge \& K. Paul.

Faulkner RO (1956) The Man who was tired of Life. The Journal of Egyptian Archaeology 42: 21-40.

Elliott AG (1987) Roads to Paradise: Reading the Lives of the Early Saints. Hanover: University Press of New England.

Evans JD (1985) Semiotics and Traditional Lore: The Medieval Dragon Tradition. Journal of Folklore Research 22 (2.3: Folklore and Semiotics), 85-112.

Fontenrose J (1980) Python. Berkeley, Los Angeles, London: University of California Press.

Forsyth N (1987) The Old Enemy: Satan and the Combat Myth. Princeton, NJ: Princeton University Press.

Frey N, Denham RD (2006) Anatomy of Criticism: Four Essays. Toronto: University of Toronto Press. [first ed. 1957].

Frey N (2013) The Stubborn Structure: Essays on Criticism and Society. Hoboken: Taylor and Francis. [first ed. 1970].

Frey N, Lee AA (2014) The Great Code: The Bible and Literature. Toronto: Penguin. [first ed. 1983].

Frey N, Denham RD (1990) Myth and Metaphor: Selected Essays Charlottesville, London: Univ. Press of Virginia.

Frey N, Dolzani M (2016) Words with Power: Being a Second Study of 'The Bible and Literature'. Toronto: University of Toronto Press. [first ed. 1990]. 
Gočeva Z (1981-1999) Hygieia. In Lexicon iconographicum mythologiae classicae (LIMC). Zurich: Artemis Verlag, (5.1): 554-572

Golan A (1991) Myth and Symbol: Symbolism in Prehistoric Religions. (trans) R Schneider-Teteruk, Jerusalem: A. Golan.

Graves R (1955) Greek Myths. London: Cassell.

Halm-Tisserant M, Gèrard S (1981-1999) Kerykeion. Lexicon iconographicum mythologiae classicae (LIMC). Zurich: Artemis Verlag, (1.1): 728-730, (1.2): 495.

Harari YN (2011) Sapiens: A Brief History of Humankind. Or Yehuda: Kinneret ZmoraBitan Dvir. (translated from Hebrew).

Heinz-Mohr G (1982) Lessicon di Iconografia Cristiana. Milan: Istituto propaganda libraria.

Hillard T (2010) The God Abandons Antony: Egyptian street theatre in 30 BC. In A Woods, A McFarlane, S Binder (eds), Z Hawas (preface), Egyptian Culture and Society: Studies in Honour of Naguib Kanawati. Cairo: Conseil supreme des antiquities de l'Egypte. 160-172.

Isbell LA (2009) The Fruit, the Tree, and the Serpent. Cambridg, Mass: Harvard University Press.

Jackson HM (1985a) The Lion Becomes Man: The Gnostic Leontomorphic Creator and the Platonic Tradition. Atlanta, GA: Scholars Press.

Jackson HM (1985b) The Meaning and Function of the Leontocephaline in Roman Mithraism. Numen 32 (1): 17-45.

Johnston C (2000) Consecrated Venom: the Serpent and the Tree of Knowledge. Edinburgh: Floris Books.

Jones KR (1981) The Serpent in the Old Testament. Ann Arbor, MI: University Microfilms.

Jones DE (2002) An Instinct for Dragons. London, New York: Routledge.

Jung CG (1919) Psychology of the Unconscious: A Study of the Transformations and Symbolisms of the Libido: A Contribution to the History of the Evolution of Thought. (trans, intro) MH Beatrice, London: Kegan Paul, Trench, Trubner \& Co.

Kaftal G (1952-1985) Saints in Italian Art. Florence: Sansoni.

Kater-Sibbes GJF (1973) Preliminary Catalogue of Sarapis Monuments. Leiden: EJ Brill.

Kessler HL (2009) Christ the Magic Dragon. Gesta 48 (2. Making Thoughts, Making Pictures, Making Memories: A Special Issue in Honour of Mary J. Carruthers), 119134.

Klein C (1988) Rethinking Cihuacóatl: Aztec Political Imagery of the Conquered Woman. Oxford: BAR.

Knight C (1983) Levi-Strauss and the Dragon: Mythologiques Reconsidered in the Light of an Australian Aboriginal Myth. Man, New Series 18 (1), 21-50.

Kripal JJ (2007) The Serpent's Gift: Gnostic Reflections on the Study of Religion. Chicago: University of Chicago Press.

Krug A (1993) Heilkunst und Heilkult: Medizin in der Antike, München: Beck.

Lakoff G, Johnson M (1980) Metaphors We Live By. Chicago, London: University of Chicago Press.

Lalonde GV (2006) Horos Dios: An Athenian Shrine and Cult of Zeus, Leiden: Brill.

Lander GB (1995) God, Cosmos, and Humankind: The World of Early Christian Symbolism. (trans) T Dunlap, Berkeley: University of California Press.

Larson J (2007) Ancient Greek Cults, New York: Routledge.

Lesko BS (1999) The Great Goddesses of Egypt, Norman: University of Oklahoma Press.

Levi D (1944) Aion. Hesperial 13 (4), 269-314.

Levi D’Ancona M (2001) Lo Zoo del Rinascimento: il significato degli animali nella pittura italiana dal XIV al XVI secolo. Lucca: M. Pacini Fazzi. 
Levi-Strauss C (1963-1983) Structural Anthropology. (trans) C Jacobson, BG Schoepf, New York: Basic Books.

Levi-Strauss C (1999 [1977]) Myth and Meaning. London: Routledge.

Lichtheim M (1973) Ancient Egyptian Literature: A Book of Readings. Berkeley: University of California Press.

Leeming DA (2013) Medusa: In the Mirror of Time. London: Reaktion Books.

Lippincott LW (1981) The Unnatural History of Dragons. Philadelphia Museum of Art Bulletin 77 (334): 2-24.

Lurker M (1980) The Gods and Symbols of Ancient Egypt: An Illustrated Dictionary with 114 Illustrations. London: Thames and Hudson.

Maré EA (2006) There is no Hero Without a Dragon: A Revisionist Interpretation of The Myth of St. George and the Dragon. Religion and Theology 13 (2), 195-203.

Mark-Weiner T (1983) Narrative Cycles of the Life of St. George in Byzantine Art. Ann Arbor, MI: University Microfilms International.

Morabito PM (2011) Saint George and the Dragon: Cult, Culture and Foundation of the City. Journal of Violence, Mimesis, and Culture 18, 135-153

Narkiss B (1978) The Sign of Jonah. Gesta, 18 (1), 63-76.

Neumann E (1954) The Origins and History of Consciousness. (foreword) CG Jung (trans) RFC Hull, Princeton, NJ: Princeton University Press.

Nickel H (1989) Of Dragons, Basilisks, and the Arms of the Seven Kings of Rome. Metropolitan Museum Journal 24, 25-34.

Noegel SB (2015) Jonah and Leviathan.Henoch37 (2): 236-260.

Ogden D (2011a) Alexander the Great: Myth, Genesis and Sexuality, Exeter, UK: University of Exeter Press.

Ogden D (2011b) The Seleucid Foundation Legends. In K Erickson, G Ramsey (eds) Seleucid Dissolution: The Sinking of the Anchor. Wiesbaden: Harrassowitz. 149-160.

Ogden D (2012) Sekandar, Dragon-Slayer. In S Richard, K Erickson, IR Netton (eds) The Alexander Romance in Persia and the East. Ancient Narrative Supplementum 15, Groningen: Barkhuis Publishing and Groningen University Library. 277-294

Ogden D (2013a) Dragons, Serpents and Slayers in the Classical and Early Christian Worlds: A Sourcebook. Oxford: Oxford University Press.

Ogden D (2013b) Drakon: Dragon Myth and Serpent Cult in the Greek and Roman Worlds. Oxford: Oxford University Press.

Pancaroğlu O (2004) The Itinerant Dragon-Slayer: Forging Paths of Image and Identity in Medieval Anatolia. Gesta 43 (2), 151-164.

Parke HW, Wormell DEW (1956) The Delphic Oracle, Oxford: Basil Blackwell.

Pedretti C, Roberts J (1984-1986) Leonardo's Horses. Florence: Giunti Barbèra.

Phillips KM (1968) Perseus and Andromeda. American Journal of Archaeology 72 (1): 123.

Reemes DM (2015) The Egyptian Ouroboros: An Iconological and Theological Study. Los Angeles: University of California.

Roberts A (1995) Hathor Rising: The Power of the Goddess in Ancient Egypt. Devon: Northgate Publishers.

Rohde E (2010) Psyche: The Cult of Souls and Belief in Immortality Among the Greeks. New York: Routledge. [first ed. 1925]

Rowland B (1975) Animals with Human Faces: A Guide to Animal Symbolism. Knoxville: University of Tennessee Press.

Schmidt K (2010) Göbekli Tepe - The Stone Age Sanctuaries: New Results of Ongoing Excavations with a Special Focus. Documenta Praehistorica 37, 239-256.

Sfameni-Gasparro G (1997) Daimôn and Tuché in the Hellenistic religious experience. In Per Bilde (ed.) Conventional Values of the Hellenistic Greeks 8. Aarhus: Aarhus 
University Press. 67-109.Smith EG (1919) The Evolution of the Dragon. Manchester: Library of Alexandria.

Sotomayor M (1961-1970) Giorgio: Santo, Martire - Iconografia. Bibliotheca Sanctorum. Rome: Istituto Giovanni xxii Della Pontificia Universita Lateranense, 525-545

South M (ed.) (1981) Topsell's Histories of Beasts. Chicago: Nelson-Hall.

Stafford E (2000) Worshipping Virtues: Personification and the Divine in Ancient Greece. London, Swansea, Oakville, CT: Duckworth, Classical Press of Wales and David Brown Bk.

Stafford E (2005) Without You No One is Happy. In H King (ed.) Health in Antiquity. Londo: Routledge. 120-135.

Stafford E (2007) Personification in Greek Religious Thought and Practice. In D Ogden (ed.) A Companion to Greek Religion. Malden, Mass: Blackwell Pub. 71-85.

Taube K (2010) Where Earth and Sky Meet: The Sea in Ancient and Contemporary Mayan Cosmology. In D Finamore, S Housto (eds) Fiery Pool: The Maya and the Mythic Sea. Salem: Peabody Essex Museum, 202-219.

Toynbee JMC (1973) Animals in Roman Life and Art. London: Biltmore.

Troy Lana (1986) Patterns of Queenship in Ancient Egyptian Myth and History. Uppsala: Universitet.

Turner AK (1993) The History of Hell. San Diego, CA: Harcourt Brace.

Ustinova Y (2005) Snake-Limbed and Tendril-Limbed Goddesses in the Art and Mythology of the Mediterranean and Black Sea. In D Braund (ed.) Scythians and Greeks: Cultural Interactions in Scythia, Athens and the Early Roman Empire (Sixth Century BC - First Century AD). Exeter, UK: University of Exeter Press, 64-79.

Wallace AJ, Rusk RD (2010)Moral Transformation: The Original Christian Paradigm of Salvation. New Zealand: Bridgehead Publishing.

Walter C (1989) The Thracian Horseman: Ancestor of the Warrior Saint? Byzantinische Forschungen 14, 659-673.

Warburg A, Mainland WF (1939) A Lecture on Serpent Ritual. Journal of the Warburg Institute 2 (4): 277-292.

Watkins C (2001) How to Kill a Dragon: Aspects of Indo-European Poetics. Oxford: Oxford University Press.

Wieck RS (1997) Painted Prayers: The Book of Hours in Medieval and Renaissance Art. New York: George Braziller.

Wilk SR (2000) Medusa. Oxford and New York: Oxford University Press.

Wittkower R (1987) Allegory and the Migration of Symbols. New York: Thames and Hudson. 